\title{
Devil's Character and Christian Tradition in European Children's Stories
}

\section{Imron Wakhid Harits, Muna AIFadlilah}

\begin{abstract}
European Fairy tales have spread out and affected other stories in the world. Since $17^{\text {th }}$ century and $19^{\text {th }}$ century when Perrault and Grimm released the literary fairy tales, it has been adapted in many versions with their own cultural characteristics. The devil is one of the characters in European tales and it is really unique due to its different perspectives in culture and tradition. This paper examines the character of the devil in three European fairy tales, Kate and the Devil, The Devil and Grandmother, and Billy Duff and the Devil. The focus of study is to probe the character of the devil from European culture and tradition from Pagan era to Christianity. To uncover the character of the devil in European children stories is elusive if it analyzes from the general/common perspective. Thus, the ethnography approach carries out to understand and analyze the devil from the European culture and tradition context. From the research, it is found that the devil in European fairy tales could be evil and kind character or somehow it could be both. The devil in the fairy tales live together with the human and they compete with the human otherwise they mostly get lost.
\end{abstract}

Key words: European Fairy tales, Culture, tradition, devil's character. 


\section{Abstrakt}

Evropské pohádky se rozširíily a ovlivnily další príběhy ve světě. Od 17. a 19. století, kdy Perrault a btaři Grimmové vydali literární pohádky, byla tato sbírka pohádek upravena v mnoha verzích s vlastními kulturními charakteristikami. Ďábel je jednou z postav $v$ těchto evropských pohádkách, která je opravdu jedinečná díky svým odlišným perspektivám v kultuře a tradici. Tento článek zkoumá charakter dábla ve třech evropských pohádkách, Kate a dábel, Ďábel a babička, a Billy Duff a dábel. Předmětem studie je zkoumat charakter dábla z evropské kultury a tradice od pohanské éry až po křestanství. Odhalit charakter dábla v evropských dětských príbězích je nepolapitelné, pokud analyzuje z obecné / společné perspektivy. Etnografický př́stup tak vede k pochopení a analýze dábla z evropského kulturního a tradičního kontextu. Z výzkumu se zjistilo, že dábel v evropských pohádkách může být zlý či laskavý charakter nebo i obojí. Ďábel v pohádkách žije společně s člověkem, soupeři s člověkem, ale jinak se většinou ztratí.

Klíčová slova: evropské pohádky, kultura, tradice, dábel/čert, postava dábla.

DOI: 10.5507/epd.2020.012

\section{Postava čerta a křestáanská tradice v evropských pohádkách}

The notion of Children stories cannot neglect the history of the fairy tales, particularly the two milestones in children literature, Charles Perrault's Histoires et Contes du temps passé (1697) and Jacob and Wilhelm Grimm's Kinder und Hausmärchen (1812-1857). At the beginning both fairy tales (Perrault and Grimm) were closely related with the gender issues in Europe. Besides the gender issues, the fairy tales in Europe also deal with the culture and tradition. Regarding the historical perspective in children literature, Nikolajeva (1995, Ewers, 1980) states the history of children literature itself deals with two main points. Firstly, the historical context in children literature related to the pedagogical view, and the second is singled out with the society. The perspective of the historical view in the history of children literature is in line with the adjustment for pedagogical context in fairy tales. For example, the brothers Grimm fairy tales have ben revised several times since its first publication in 1812 to fit with the children moral values and standards.

Furthermore, Zipes in his interview with the Guardian stated that the Grimm made the change in later editions because they "held motherhood sacred", but that there were sociological grounds for the change - beyond the fear of offending potential readers - because "many women died from childbirth in the 18th and 19th centuries, and there were numerous instances in which the father remarried a young woman, perhaps 
close in age to the father's eldest daughter," of whom the new wife might feel jealous (https://www.theguardian.com/books/2014/nov/12/grimm-brothers-fairytales-horrornew-translation). The first version of Brothers Grimm was unsuitable for the children as for example the mothers in Snow White and Hensel and Gretel and the pregnancy of Rapunzel. Later on, based on the society perspective, the history of children literature examines the tradition and social values of children literature. Because mostly the children stories derived from the folktales, the story that was originated from the tradition of the particular society, thus the history of children literature contains the mythical creatures from the pagan untill the Christianity tradition.

One of the mythical creature in the children story is the devil. The perspective of the devil in the society is a bad character but it does not carry over for all societies. The devil may appear looking like an animal, a man or natural phenomenon; however, the prevalent appearance is the anthropomorphic image with or without special features (for instance, one leg as a beast's leg) (Straubergs,1941, Celmin, Keirāne, 2019). Indeed, the devil is a part of Angels and they could choose for following of God or they could contravene God. All of Angels are created by good character but they have a freedom for rebelling to devil and leaving their position as a servant from God. However, most of the Angels choose to follow God and to work for him, the other hand some of the Angels going for working the devil instead. It sometimes the devil only tries to trick human to do bad things.

\section{Literature Review}

Mostly the devil in European fairy tales is not the frightened creature, but it is more the silly creature who usually get lost when they compete with the human being. The form of the devil could be in many creatures such as Ogre, troll, and goblin. occasionally the goblin is replaced by the ghost, devil, goblin, troll, and other wicked creatures (Harits, $2016,310)$. They are not really haunted and they are easily cheated. The mythological Devil of the Balts [...] is the inversion of the wise God; the stupid face of the God. The fairy tale Devil is a fool. His animal attributes (tail, claws, ears) show his genetic connection with animal symbols, which in the religions of the Stone Age referred to the power of God - life, fertility" (Taivāns, 1992, Celmiṇa-K̦eirāne, 2019).

Also, the devil character in European fairy tales was sourced from the bible. According to Heaster (2007) from the first book of the Bible (Genesis) to the last (Revelation), the existence of the devil as a real, literal adversary is affirmed. Genesis is the kinds of Epistle in the Holy Bible which can be found in the Old Testament Our first introduction to Satan occurs in Genesis 3 as he arrives on the scene in the form of a serpent to tempt Eve (p. 121). Satan truly is the greatest adversary. In fact, the name "Satan" is simply a transliteration from Hebrew into both Greek and English. The Hebrew word means 
adversary or opponent. It was used as human adversaries in 1 Samuel 29:4; 2 Samuel 19:22; 1 Kings 5:4; 1 Kings $11: 14,23,25$; and Psalm 109:6. Even the Angel of the Lord was called a"Satan" when He stood in the road as an adversary to Balaam (Num. 22:22). In the Old Testament refers to the devil as "Satan" also Satan is the adversary (Reim, 2005 p. 1). Devil as a character in christianity is portrayed as the evil one. He is contrary to God. It is strange but true: the belief in the Devil is alive. This fact is brilliantly argued by Robert Muchembled (2003) in his book A History of the Devil: From the Middle Ages to the Present. He says: "In fact, for almost a thousand years, he had never really gone away. The devil has been part of the fabric of European life since the Middle Ages, and has accompanied all its major changes" (p. 1).

\section{Research Method}

This study uses a descriptive way in qualitative research; the analysis focuses on the utterances in children stories. It is intended to explore the Devil as a character in European fairy tales. This study employs the qualitative research method by using library research. Library research is useful to be applied in gathering data, because it aims to collect data from written sources useful for the analysis. The method of library research was used to analyse both the children's literature and the documents. An ethnography approach was used to explore and probe the multicultural contexts, such as traditions, culture and history in children stories. The research deals with multiculturalism, conducts with the participation of the subject, with the data observed and interpreted (Denzin and Lincoln, 2011).

\section{Discussion}

Further, dealing with the mythical charcters particularly the devil character in the children stories, here I discuss three children stories from Europe portaying the Devil both as the main character and the supporting character. First story is The Devil and His Grandmother, it is the story from Brother Grimm, the second is The Devil and Kate written by Bozena Nemcova, the last is Billy Duff and the Devil, the children story from Peter Henry Emerson, the British writer. Later on, each devils' characters from the three stories will discuss it below,

\section{A. Devil Character's in The Devil and His Grandmother story}

The Character of the devil in The Devil and His Grandmother story is grumpy. The first, the devil is much more happily because the three soldiers will serve the dragon according to their treaty before, but they can answer the riddle from the dragon then the dragon 
was angry. The function of the riddle is one of the challenges for them because devil thinks the riddle is difficult enough and the devil surely getting serve from them. Such as in this quotation,

"The Devil was angry, and began to mutter" hmm hmm hmm!"

It has a meaning, the devil was angry after they answer all the riddle with the true answers, because when they answer the riddle, then the devil will be weak, it was the reason why the devil was angry too. Naturally, the grumpiness is the characteristic of the devil. Also, The bad character of the devil is the fate given from God, such as the devil could come in human life with the big opportunity for being grumpy.

Based on the story the devil's grandmother has a good character such feeling pity and sympathy to the human being. For example, when she helps the soldiers to hide, from the dragon. The devil's grandmother suggests to the soldier concealing himself from dragon's chase, it proves her caring to the human being. On the other hand, some of the devils has the evil characters, for an instance in the story of the devil and his grandmother has different character, exactly has contrary character by herself. Sometimes, the devil asks the compensation to human for serving him. It likes mention it in the text, "If you serve me for seven years," said the dragon, "I will convey you through the army so that no one shall seize you.

The situation above is when the soldiers want to serve the dragon and as the consequences the dragon will not seize the soldiers as compensation. The three soldiers should fulfill all the dragons wish and the dragon gives anything the soldiers will. One of the dragon wish is to serve him the prey that can bring him returning back to the hell. The next devil's character based on the story is Impersonating. This is the character to change into another form. One of the example is the changing as the dragon. It mentions in the story's quotation:

"Then the dragon caught hold of them with his claws, and carried them away through the air over the army, and put them down again on the earth far it; but the dragon was no other than the devil.

Generally all devils has ability for impersonating, such as he could change into other forms like human, animals, or angel. In this story, the devil change into the dragon and bring the three soldiers with his claws. The aim of the dragon changes her body to be a dragon is to show his strenght and his mythical power.

\section{B. Devil Character's in The Devil and Kate}

Unlike the character of the devil in the previous story, the character of the Devil in The Devil and Kate by Nemcova is foolish. The story tells about the character of the Devil who asks Kate in any conditional statement such as in the narration as follows:

"If all of them are as stupid as he is, it is good for us" 
This is happened while the devil lied to shepherd. The word "stupid" here refers to the Devil's. In the story, the Devil wants to carry Kate to the nearest village and get rid of her. On his journey, the Devil meets the shepherd and asks him for helping because his legs are sinking. The shepherd helps the Devil and he promises to get rid of Kate from the devil under any agreement. The shepherd cheats the Devil under the agreement between both of them. Once, the devil returns to hell and reports to the Old Devil, the Devil is just aware of his stupidity, like in the quotation below,

"That because you are fool and you don't remember my warnings," the old Satan inveighed against him.

The next character of the Devil in this story is impersonating too. The Devil could be changing into another form. According to the story, the devil changes into the man, a handsome man. The aims of impersonating is for tricking and building the trust when the devil wants to have purpose to do bad or good for the humans in the world. Nobody knows he is impersonating into a human, because the shepherd does not know who he is. Whether the devil could be changed into any forms both women or man. Meanwhile, the devil in thie story changes in disguising because he wants asking a help from the shepherd for getting rid of Kate.He does not want anybody recognizing him as the Devil when he asks for a help like when he asks the shepherd' help.

According to the story, when the old Satan wants to get rid of the devil from the hell, due to his foolish for not attend the Old satan warning about Kate. The devil asked Kate for dancing, bringing her to the hell and willing to marry with her. The Old devil was angry and asked the Devil to overcome his problem on earth. Unluckily, his bad tempered makes him cannot think positively, and finally he is cheated by the shepherd. The shepherd becomes a great person, as the king's advisor and the foolish devil returns back to the hell with nothing.

\section{Devil Character's in Billy Duff and the Devil}

The third is the character of the devil in story of Billy Duff and the Devil. Based on the story, the character of the devil is miserable. The devil gets the bad treatment from Billy. Even though, he comes to Billy for asking the promise that he sells himself to the devil and he always gets the torture from Billy because he does not want to join the devil in hell. It depicts in the quotation below,

The devil got awful savage, and blackguarded Billy Duffy terribly; but it was useless. Billy key him there for days, till got civil and said:"Mr. Duffy, what will you let me go for?"Only one thing: I am to live the rest of my live without you, and have as much gold as I like" The devil gets an awful savaging in the Billy's house. The devil gets bad treatment from Billy. The bad luck of the devil will finish untill Billy lets the devil leave. The story of Billy Duff and the devil was touching because of the devil laid of Billy, while the devil invites him to the hell. However, the devil has the fatefully character, he wants to receive the 
offering when Billy said until he himself is uncontrolled. Because the devil only asks to Billy to go to hell together with his promise for selling himself to the devil when he gets drunk. On the other hand, he gets hurt and resists Billy.

\section{Conclusion}

The children stories as a result of culture and tradition have their own character and uniqueness, such as in their character of the story. The European tales emerge with their own uniqueness in any myhical characters like the devil. Though its character is sourced from the Bible, but the writer has given the different touches among them. The three stories with the devil as the character give the different perspective of the devil's character in the children stories. The devil has both kind and evil character in the story. Though, mostly the devil gets lost while they compete with the human. In Kate and the Devil for an instance, the devil was easily tricked and pranked by the shepherd. It also is happened in Billy Duff and The Devil when the devil follows all Billy's instruction. While, in Grimm's The Devil and Grandmother, both devils have the opposite character, both good and bad. The characters of the devil in European fairy tales are a derived from its social values, tradition, and culture from the pagan era and it is combined with the Christianity tradition in Europe.

\section{Acknowledgement}

UTM 2019 Mandiri Research.

\section{References}

Celmiņa-Ķeirāne, A. (2019). The Character of The Fairy Tale Devil in The Graphics Of Latvian Books: The First Half Of The $20^{\text {th }}$ Century. Human, Technologies and Quality of Education. In Daniela, L. (ed.). Human, Technologies and Quality of Education, 2019. Proceedings of Scientific Papers. Riga: University of Latvia.

Denzin, N. K., \& Lincoln, Y. S. (2005). The SAGE handbook of qualitative research. Thousand Oaks: Sage Publications.

Erben, K. J. \& Nemcova, B. (2014). Czech Fairy Tales. Praha: Vitalis.

Heaster, D. (2007). The real A Biblical Exploration. South Croydon: Carelink Publishing.

Harits, I. Chudý, Š. (2016). The Legend Of Vodnik (Water Goblin): Slavic Tradition And Cultural Adaptation. In The 5th ELTLT Conference Proceedings. October 2016. World Englishes in Language Teaching, Literature, and Translation in the Context of Asia. Semarang: State University of Semarang. 
Harits, I. W. et al. (2015). Vicarious Experience by Modeling and Comparing of Children Stories from Czech and Madura Island: Behaviour and Moral Perspectives. Creative Education, 6, 683-691. Hazard, P. (1944). Books, Children, and Men. Boston: The Horn Book.

Hunt, P. (2011). Children's Literature. In Nel, P., \& Paul, L. Keywords for children's literature. New York: New York University Press.

Nikolaveja, M. (2008). Comparative Children's Literature: What is There to Compare? Papers: Explorations into Children Literature, 18(1), 30-40.

Parsons, E. (2011). Ideology. In Nel, P., \& Paul, L. Keywords for children's literature. New York: New York University Press.

Reim, D. (2005). An Overview of the Origin of Satan Part Il: The AllowedActivities of Satan. Journal of Theology, 45(1).

Straubergs, K. (1941). Latviešu buramie vārdi [Latvian Spells] (Volume 2). Rīga: Latviešu folkloras krātuve.

Straubergs, K. (1944). Latviešu tautas paražas [Latvian Folk Customs]. Rīga: Latvju Grāmata.

Taivāns, L. G. (1992). Baltu reliǵija un kristietība. Tipoloǵiskas rekonstrukcijas principi [Religion of Balts and Christianity. Principles of Typological Reconstruction]. Celšs, 1(44), 18-32.

\section{Online References}

https://www.theguardian.com/books/2014/nov/12/grimm-brothers-fairytales-horror-newtranslation

German Culture. (2019). Library. Retrivied on 12 April 2019. Tradition and Culture of Germany. https://germanculture.com.ua/library/

Emerson, P. H. Billy Duff and The Devil. Retrieved from https://fairytalez.com/billy-duff-and-thedevil/

\section{Contacs:}

Imron Wakhid Harits, Ph.D.

Muna AIFadlilah

Universitas Trunojoyo Madura

Madur, Jawa Timur, Indonesia

e-mail: imronwakhidharits@gmail.com

Imron Wakhid Harits, Ph.D. is an Associate Professor in Children Literature and English Education, he is also the Director of International Office UTM. His publication link https://www. researchgate.net/profile/Imron_Harits/publications. He graduated in Language and Literature Education, State Surabaya University, Indonesia (Master) and Institute on Education and Social Studies, Palacky University Olomouc, Czech Republic (PhD). He also joined with some nondegree courses in USA, China and Slovenia. He is working as the member of editorial boards and reviewer of several scientific journals.

Muna Alfadlilah graduated from Trunojoyo Madura University in 2019. The major is English literature. During in college the writer wrote several scientific articles to be published in journals, as well as participated in several competitions from national and international levels. currently an English tutor in Yogyakarta. His hobbies are writing and reading. His life motto is that experience as an asset to life. 